\title{
IMMUNOFLUORESCENT ANTIBODY TO ROTAVIRUS AND ANTIGEN EXCRETION IN INFANTILE ACUTE DIARRHOEA.
}

\author{
C.M. NOZAWA, E. LAMPE; M.G.S. VAZ \& M.G. von HUBINGER
}

\begin{abstract}
SUMMARY
A serological study was carried out to evaluate the causal relationship of acute diarrhoea and rotavirus in children under five years of age. The rotaviral infection was demonstrated in paired sera by determining the antibody titers by immunofluorescence test (IF). Bovine rotavirus-infected MA-104 cell culture was used as substratum for IF. Out of 80 paired sera it was shown that $23(28.75 \%)$ presented seroconversion, $19(23.75 \%)$ samples showed a twofold increase in their titers and $38(47.5 \%)$ had no increase in rotavirus antibody. This result is discussed on the light of previously obtained results on viral antigen detection by counterimmunoelectrosmophoresis (CIEOP).
\end{abstract}

KEY WORDS: Rotavirus antigen; Paired serology; Immunofluorescence test.

\section{INTRODUCTION}

Rotavirus is the major causal agent of viral diarrhoea in young children ${ }^{3}$. Detection of rotaviral particles or their antigens in stools by different methods is well established and routinely performed. However one has to bare in mind that viral detection only does not necessarily mean that infection by rotavirus has occurred. In fact, for many viral diseases the isolation of an agent has to be followed by serology (seroconversion) to confirm the infection, unless under circumstances that viruses are detected in sterile body fluid. On the other hand paired serology alone can define an infection.

It is well known that enteric viruses can be transient in faeces causing no disease at alls. Rotavirus by its turn can be eliminated in faeces by simptomless babies ${ }^{2}$. Rotavirus serology has been carried out in many countries including Brazil $4,7,9,10$.

This work shows the result of a serological study in which immunofluorescent antibody to rotavirus was titered in paired sera originating from hospitalized children suffering of acute diarrhoea.

\section{MATERIAL AND METHODS}

Paired sera: Sera were collected from children under five years of age hospitalized at Instituto Fernandes Figueira - Rio de Janeiro city. Serum samples were separated from blood withdrawn from forearm peripheral vein. Chilaren were bled twice, as soon as diarrhoea started (meantime of 4 days) and twenty days later. At the laboratory serum samples were inactivated at $56^{\circ} \mathrm{C}$ for $15 \mathrm{~min}$. in water-bath and stored at $-20^{\circ} \mathrm{C}$. A twofold dilution of sera was prepared in phosphate buffer-saline (PBS) pH 7.3 from 1:2 to 1:256 for antibody titration.

Bovine rotavirus cultivation in cell culture: Bovine rotavirus (UK strain) was cultivated in MA-104 (Rhesus foetal kidney cells) in MEM Eagle (Flow Lab. USA) added of crystalline trypsin (Interm. Com. \& Ind., S. Paulo) at final concentration of $30 \mu \mathrm{g} / \mathrm{ml}$ in Roux flasks 6 .

Antibody titration by indirect immunofluorescence (IF): A five-day old postinoculation infected tissue culture was used to prepare the MA-104 infected cell suspensions. A mock-infected tissue culture was also used

Department of Virology. Instituto de Microbiologia da Universidade Federal do Rio de Janeiro. Caixa Postal 68040. 21944 - Rio de Janeiro, RJ, Brasil. 
NOZAWA, C.M.; LAMPE, E.; VAZ, M.G.S. \& HUBINGER, M.G. von - Immunofluorescent antibody to rotavirus and antigen excretion in infantile acute diarrhoea. Rev. Inst. Med. trop. São Paulo, 30(5):332-335, 1988.

for control. After standardization, a drop of infected and mock-infected cells was placer in each square previously demarcated in a microscope glass slide, let them dry and fixed. For each square of dried cell suspension a drop of diluted serum was used in duplicate9. For IF FITC-goat anti-human Ig (Oxford Lab., USA) diluted at $1: 25$ in PBS was used. The preparation was observed in a Leitz UV microscope fitted with $\mathrm{BG}-12, \mathrm{BG}-13$ and $\mathrm{K}$ 510 set of filters and darkfield condenser. The patients antibody titer was considered the highest serum dilution where citoplasmic granular-patterned specific fiuorescence (Fig. 1) could still be detected in at last $10 \%$ of the cells per microscope field (obj. 40X). The lowest serum dilution was tested at the same time for inespecific fluorescence in mockinfected cells.

Antigen detection by counterimmunoelectrosmophore is (CKOP)

Rotaviral antigen detection by CEPOP was done with $20 \%$ (v) clarifled apcal homogenates in a $0.6 \%$ agarose gel prepared in veronal-acetais buffer $\mathrm{pH} 8.7$ and tested against rabbit ani-human rotavirus serum by a ninety-minute electrophoretic run at $4 \mathrm{~mA}$, such as previously described8.

\section{RESULTS}

Out of 180 children suffering from acute diarrhoea we could only select 80 from whom paired sera were available. In many cases we could not obtain the second serum sample because of the healling and subsequent discharging of the children from the hospital. In some cases the children were so debilitated that bleeding was considered an unnecessary harm. Therefore out of 80 paired serum samples it was found that $28.75 \%(23 / 80) \mathrm{had}$ seroconversion evidenced by a rise in rotavirus antibody by at least fourfold. In order to exclude the possibility of fluorescence due to the inespecific binding of the conjugate antibody to cell, the same dilution of the conjugate antibody $(1: 25)$ was tested in infected cells and no fluorescence was observed.

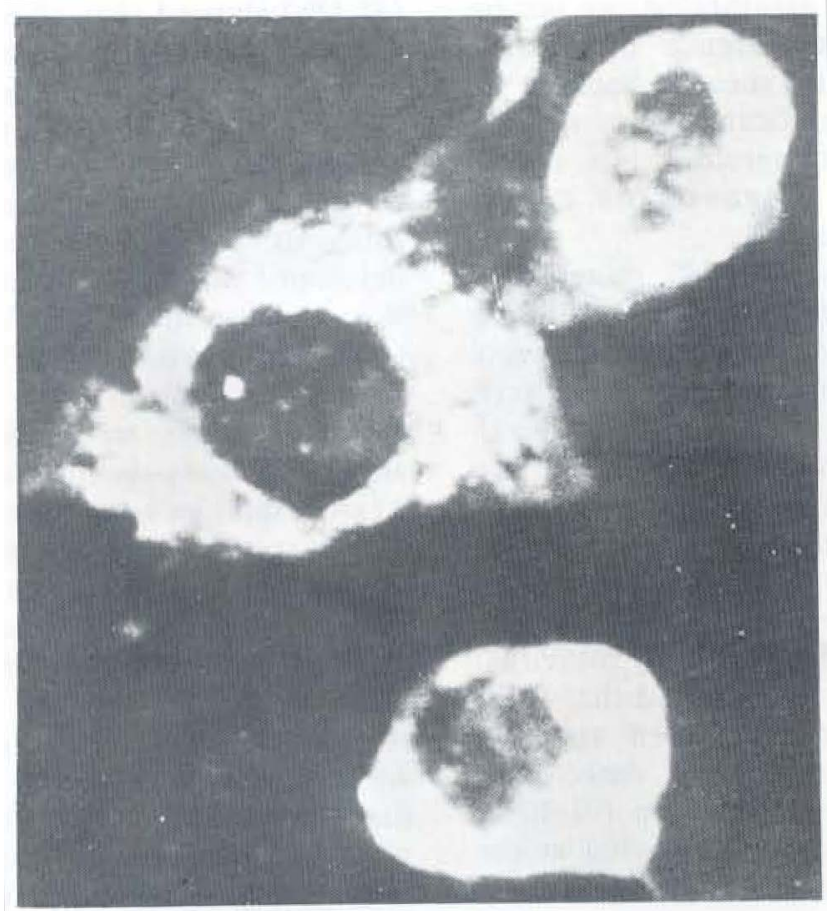

Fig. 1 - Bovine rotavirus-infected MA-104 cells harvested 48 h. post-infection and used as substratum for immunofluorescent antibody titration in patients sera. Specific cytoplasmic granular fluorescence is shown. Magnification, $250 \mathrm{X}$. 
NOZAWA, C.M.; LAMPE, E.; VAZ, M.G.S. \& HUBINGER, M.G. von - Immunofluorescent antibody to rotavirus and antigen excretion in infantile acute diarrhoea. Rev. Inst. Med. trop. São Paulo, 30(5):332-335, 1988.

Unespectedly from 80 paired sera the antibody titer rose twofold in $23.75 \%(19 / 80)$. These nineteen paired serum samples were re-tested one week later and no difference in their titers was detected in comparison to the previous results. Lastly from the 80 paired serum samples $47.5 \%(38 / 80)$ had no increase in their antibody titers. The fluorescent antibody titers in the patients sera varied from $1: 8$ to $1: 256$.

Previously obtained results ${ }^{8}$ studying faecal samples originating from these childen $(80)$ for rotaviral antigen by CIEOP revealed that 48 children $(60.0 \%)$ were excreting rotavirus antigen at the time of faeces collection. iwentyeight children were negative $(35.0 \%)$ and from 2 , stools were not available.

\section{DISCUSSION}

The detection of rotaviral particles or their soluble antigens in acute diarrhoeic faeces by any of the available laboratorial methods, is suggestive of causal relationship with diarrhoea. However one can not be sure unless otherwise proved. That assumption can not be accepted even in the absence of known diarrhoea-causing agents, such as bacteria or parasites. Therefore significant rise in specific antibody titer (seroconversion) has to be detected before the diagnosis of causal relationship is confirmed.

In this report we studied 80 paired sera samples collected from hospitalized children under five years of age suffering of acute diarrhoea. It was shown that 23 out 80 paired serum samples $(28.75 \%)$ had significant rise in specific immunofluorescent antibody to rotavirus. This result undoubtedly means that, children from whon paired sera were collected and showed at least fourfold increase in specific rotavirus antibody, (seroconversion) were in fact suffering of diarrhoea caused by rotavirus. Previously obtained results ${ }^{8}$ showed that from 23 children who seroconverted specific precipitin lines of rotavirus antigen, detected by CIEOP, were found in 21 children $(91.30 \%)$ whose diarrhoeic faeces were collected at the time of diarrhoea onset. Unfortunately for some reason two faecal samples were not available. These results showed that rotavirus entered in contact with patients immune system in parallel with viral replication in the intestine, viral antigen was excreted and the subsequent rise in antibody level, as show by seroconversion detected by IF.

Fifty-seven paired sera samples did not show seroconversion however $19 \quad(33.33 \%)$ demonstrated an increase in the antibody titer of two times, i.e., the titer of antibody in the convalescent sera doubled in comparison to acute phase sera. CIEOP of faeces originating from those 19 children who had their antibody doubled demonstrated rotaviral antigen in 17 $(89.47 \%)$ and 2 were negative. The 19 paired sera were re-tested to rule out any technical error however the results confirmed the twofold rise. It is possible that those children developed diarrhoea caused by rotavirus but somehow the antibody response was delayed. It would be interesting to have them bled later instead of twenty days after the first bleeding. Alternatively the study of immunological aspects of those children could provide clues for the delay in the antibody response. It was difficult to group the children under a unique background unless that most of them were malnourished in varying degrees.

The analysis of the remainder 38 paired sera $(47.5 \%)$ showed that although in most of the sera a low antibody titer was observed there was no increase at all. This shows that those children were exposed to rotavirus in the past but diarrhoea they were presenting at the time of specimens collection was not due to rotaviuus. This also demonstrated that children developed antibody to rotavirus early in life. When their faecal samples were studied by CIEOP 8 it was found that 10 children $(26.31 \%$ ) out of 38 that did not reveal any rise in antibody titers were eliminating rotaviral antigen. Twenty-six children were negative and 2 faecal samples were not available. We assume that in spite of viral antigen presence in faeces diarrhoea was not due to rotavirus for immunofluorescent antibody detected in all children did not show any increase in their titers. As for other enteric viruses ${ }^{5}$, in this case rotavirus was transient in gastrointestinal tract without being the causal agent of the acute diarrhoea. Another probability though the least possible but can not be ruled out is an impairment of children circulating immune response. The transient presence of virus in faeces seems to be more plausible, as previously ${ }^{5}$ commented. In fact, a recent report was published in which a state of carrier was defined in healthy children who showed 
NOZAWA, C.M.: I.AMPE, E; VAZ, M.G.S. \& HUBINGER, M.G. von - Immunofiuorescent antibody to rotavirus and antigen excretion in infantile acute diarrhoea. Kev. Inst. Med. trop. São Paulo, 30(5):332-335, 1988.

elimination of rotavirus in faecest. This findings brought about a novel and rather important aspect in the epidemiology of rotaviral infection and strengthen the necessity of serology before the causal relationship is established.

\section{RESUMO}

\section{Sorologia pareada por imunofluorescência e excreção de antígeno de rotavírus na diarréia aguda infantil.}

Realizamos este estudo para avaliar a relação causal diarréia aguda e rotavírus em crianças abaixo de cinco anos de idade. A infecção viral foi caracterizada pela sorologia pareada, por meio de titulação de anticorpos antirotavírus pela reação de imunofluorescência indireta (IF) nos soros dos pacientes. Utilizamos como substrato para a reação células MA-104 infectadas com o rotavirus bovino cepa UK. De 80 amostras de soros pareados, verificamos que 23 amostras $(28.75 \%)$ apresentaram sorocolversão, 19 amostras $(23,75 \%)$ tiveram elevaçào no título de 2 vezes e em 38 amostras $(47,5 \%)$ não observamos elevação no título de anticorpos anti-rotavírus. Estes resultados são confrontados com os resultados previamente obtidos na deteção do antígeno de rotavirus nas fezes, dos mesmos pacientes, pela técnica de contraimunoeletroforese (CIEOP).

\section{ACKNOWLEDGEMENTS}

This study was partially financed by grants from FINEP, CAPES, CNPq and CEPGUFRJ. We thank to Dr. M. Krieger (Instituto Fernandes Figueira - Rio de Janeiro) for supplying clinical specimens, Mrs. E.B.
Ferrarezi for typing the manuscript and $\mathrm{Mr}$. P.R.A Rios for the photographic art.

\section{REFERENCES}

1. CHAMPSAUR, H.; QUESTIAUX, E.; PREVOT, J.; HENRY-AMAR, M.; GOLDSZMIDT, D.; BOURYOUANE, M. \& BACH, C. - Rotavirus carriage, asymptomatic infection, and disease in the irs! two years of life. 1. Virus shedding. J infect. Dis., 149:667$674,1984$.

2. CHRYSTIE, I.L.; TOTTERDELL, B.; BAKER, M.J.; SCOPES, J.W. \& BANATVALA, J.E. - Rotavirus infections in a maternity unit (letter). Lancet, 2:79, 1975.

3. ESTES, M.K.; PALMER, E.L. \& OBIJESKI, J.F. Rotaviruses: a review. Curr. Top. Microbiol. Immunol., 105:123-184, 1983.

4. GHOSE, L.H.; SCHANGL, R.D. \& HOLMES, I.H. - Comparison of an enzyme-linked immunosorben assay for quantitation of rotasirus antibodies with complement fixation in an epidemiological survey. $\mathbf{J}$. clin. Microbiol., 8:268-276, 1978.

5. JAWETZ, E.: MELNICK, J.L. \& ADELBERG, E.A. - Review of medical microbiology. $17^{\text {th }}$ ed. California, Appieton \& Lange, 1987. p. 435-438.

6. L AMPE, E. - Pesquisa de rotavírus em crianças com gastrenterits: Rio de Janeiro, 1982 (Dissentaçäo de Mestrado -..- Instituto de Microbiologia da Universida de Federal do Rio de Janeiro).

7. LINHARES, A.C.: PINHEIRO, F.P.; FREITAS, R.B.; GABBAY, Y.B.; SHIRLEY, J.A. \& BEARDS, Ci..- - An outbreak of rotavirus diarrhoea among a nonimmune isolated South American indian community. Amer. J. Epidemiol., 113:703-710, 1981.

8. NOZAWA, C.M.; LAMPE, E. \& VAZ, M.G.S. - Dctection of rotaviral antigen by immunoprecipitation in agarose gci. Rev. bras. Pat. Clín.. 24:2-5, 1988.

9. SALIES GOMES, F.L.; SAKUMA, M.E.; CURTI, S.P. \& TAKIGUTI, C.K. - Freqüência de anticorpos para rotavirus em habitantes da cidade de São Paulo em 1980-82. Kev, paul. Med., 101:127-132, 1983.

10. SANEKATA, T.; YOSHIDA, Y.; ODA, K. \& OKADA, H. - Detection of rotavirus antibody by inhibition of reverse passive hemagglutination. J. clin. Microbiol., 15:148-155, 1982.

Recebido para publicaçào em 28/10/1987. 